WOJCIECH ŚWIECICKI

MAGDALENA GAWLOWSKA

ANDRZEJ GÓRNY

DOMINIKA RATAJCZAK

ALICJA NIEWIADOMSKA

LECH BOROS

Instytut Genetyki Roślin PAN

Kierownik Tematu: prof. dr hab. Wojciech Święcicki Instytut Genetyki Roślin PAN, ul. Strzeszyńska 34, 60-479 Poznań tel. (+48 61) 65 50263, 6550255 fax: (+48 61) 6550301, e-mail: wswi@igr.poznan.pl

Prace zostały wykonane $w$ ramach badan podstawowych na rzecz postęp biologicznego w produkcji roślinnej na podstawie decyzji Ministra Rolnictwa $i$ Rozwoju Wsi nr HOR.hn.802.18.2018, Zadanie 40.

\title{
Identyfikacja rejonów w genomie grochu, warunkujących wybrane parametry sprawności fizjologicznej, jako istotnego elementu odporności na stresy abiotyczne
}

Identification of the regions in the pea genome, responsible for selected parameters of physiological efficiency, as an important element of resistance to the abiotic stresses

Słowa kluczowe: efektywność wykorzystania azotu i fosforu u grochu, markery molekularne, QTL, współczynnik tolerancji na stres

Uzyskany postęp hodowlany $\mathrm{w}$ minionych kilkudziesięciu latach był przede wszystkim konsekwencją poprawiania indeksu żniwnego. Dalsze rezerwy w zwiększaniu produktywności roślin tkwią $\mathrm{w}$ odporności na stresy abiotyczne i biotyczne. Dlatego szczególne znaczenie mają badania nad efektywnością procesów fizjologicznych roślin. Groch wykorzystuje azot atmosferyczny poprzez jego biologiczne wiązanie. Proces zachodzi z wykorzystaniem energii zgromadzonej podczas fotosyntezy. W warunkach optymalnych proces ten zabezpiecza zapotrzebowanie rośliny na azot. Jednak w warunkach stresu, wpływającego na fotosyntezę (susza, niedobór fosforu) zaopatrzenie w azot okazuje się niewystarczające (Fischinger i Schulze, 2010). Przypuszcza się, że lokalizacja 
w genomie rejonów efektywności wykorzystania azotu i fosforu u grochu pozwoli na określenie wzajemnych relacji ze sprawnością fotosyntezy i wylegania roślin. Poprawa architektury i stabilności łanu grochu, ilościowe i jakościowe ulepszanie plonu, zwiększenie efektywności procesu wykorzystania azotu oraz odporność na stresy biotyczne i abiotyczne należą do kluczowych kierunków badań z zakresu postępu biologicznego.

W 2018 doświadczenie szklarniowe i polowe dotyczyło dwóch różnych populacji: szklarnia [Carneval $\times$ MP1401, afila $\times$ afila], doświadczenie polowe [Wt10245 $\times$ Wt11238, acacia $\times$ forma tradycyjna]. Plon $\mathrm{z}$ doświadczenia szklarniowego był zbliżony w warunkach optymalnych i w warunkach stresowych do plonu z 2017 r., dla tej samej populacji mapującej. Linia MP1401 wytwarzała wyższy plon niż linia Carneval (warunki szklarniowe, warunki stresowe). Charakteryzowała się lepszymi lub podobnymi do drugiej linii parametrami wykorzystania azotu, natomiast gorszymi parametrami wiązania azotu. W badanych liniach potomnych, w warunkach kontrolowanych, w stresie azotowym malał parametr wykorzystania azotu - azotowy indeks plonu NHI. Wartość efektywności wykorzystania azotu w formowaniu masy generatywnej $\left(\mathrm{NER}_{\mathrm{gen}}\right)$ również malała. Parametry wiązania azotu wzrastały w niedoborze azotu. Stresowe warunki polowe redukowały plon w populacji [Wt10245×Wt11238] o ok. 24\% w Przebędowie i o $17 \% \mathrm{w}$ Wiatrowie na stanowisku słabym. Indeks plonu pozostawał na zbliżonym poziomie. Stwierdzone wartości, efektywności wykorzystania azotu w formowaniu ziarna $\left(\mathrm{NER}_{\mathrm{gen}}\right)$ i aktywności nitrogenazy w populacji [Wt10245×Wt11238] były niższe, niż stwierdzone w tej samej populacji w roku poprzednim. Wartość azotowego indeksu plonu (NHI) była wyższa niż w roku 2017.

W warunkach kontrolowanych zaobserwowano istotną, pozytywną korelację $(\mathrm{p}<0,05)$ pomiędzy plonem $\mathrm{z}$ rośliny, a azotowym indeksem plonowania $\mathrm{i}$ efektywnością wykorzystania azotu $\mathrm{w}$ formowaniu masy nasion. W warunkach niedoboru azotu korelacje pomiędzy plonem, a parametrami gospodarki azotowej malały. W warunkach polowych stwierdzono istotne korelacje $(\mathrm{p}<0,01)$ pomiędzy plonem $\mathrm{z}$ rośliny, a efektywnością wykorzystania azotu w kształtowaniu nasion (NER gen) (Wiatrowo optym. 0,72, Wiatrowo niskie 0,67, Przebędowo stresowe 0,62). Istotna była również negatywna korelacja pomiędzy plonem $\mathrm{z}$ rośliny, a efektywnością wykorzystania azotu w formowaniu masy wegetatywnej $\left(\mathrm{NER}_{\mathrm{veg}}\right.$ ) (Wiatrowo optym. -0,65, Wiatrowo niskie $-0,62$, Przebędowo stresowe -0,44). Parametry gospodarki azotowej u grochu znacząco wpływały na wysokość plonu. Im bardziej stresogenne środowisko, tym niższy był udział parametrów fizjologicznych $\mathrm{w}$ kształtowaniu plonu w badanym w tym roku zestawie linii. W warunkach polowych widoczny był wzrost aktywności nitrogenazy w porównaniu z warunkami szklarniowymi $\left(810\right.$ wobec $70 \quad \mathrm{nMC}_{2} \mathrm{H}_{4} /$ roślinę/godzinę w warunkach optymalnych; 271 wobec $99,4 \mathrm{nMC}_{2} \mathrm{H}_{4} /$ roślinę/godzinę w warunkach stresowych). Należy pamiętać, że w warunkach szklarniowych i polowych testowano 2 różne populacje mapujące. Linia rodzicielska Wt10245 wykazała mniejszą wartość współczynnika tolerancji w porównaniu do linii Wt11238 dla obydwu polowych lokalizacji stresowych $\mathrm{w}$ odniesieniu do lokalizacji optymalnej. Doświadczenie szklarniowe pozwoliło na wyznaczenie współczynnika tolerancji na niedobór azotu 
(warunki kontrolowane). Linia Carneval wykazała wyższą tolerancje na niedobór azotu niż linia MP1401. Natomiast współczynniki tolerancji wyznaczone z doświadczeń polowych wskazywały na tolerancję nie tylko na niedobór azotu, ale również na nadmiar fosforu, potasu, wapnia, niedobór Fe, Zn, Mn. Przebędowo uznano za lokalizację stresową ze względu na niedobór zawartości azotu, duży nadmiar wapnia, niedobór Fe, Mn, wysokie $\mathrm{pH}$.

Efektywność wykorzystania azotu i fosforu u grochu to parametry silnie skorelowane ze wzrostem i produktywnością roślin. Jednym ze sposobów zwiększania wykorzystania fosforu jest minimalizowanie akumulacji $\mathrm{P}$ w glebie $\mathrm{w}$ formach związków organicznych i mineralnych. $Z$ tej przyczyny dla praktyki rolniczej niezbędne jest rozpoznanie możliwości stopnia wykorzystania fosforu przez roślinę, który w przeszłości uległ nagromadzeniu. Poprzez właściwy dobór gatunków roślin możliwe jest utrzymanie żyzności gleby i ograniczenie strat składnika. Główna idea uprawy roślin nastawiona jest na zwiększenie udziału roślin motylkowatych $w$ procesie efektywniejszego wykorzystania fosforu (Gaj, 2013). Linia rodzicielska Wt10245 miała wyższą niż Wt11238 wartość fizjologicznej efektywności wykorzystania azotu NERg, ale niższą fosforu PERg. Efektywność wykorzystania fosforu PERg była niższa o 18\% niż w 2016 (157 w $2016 \mathrm{mg} / \mathrm{mg}, 128 \mathrm{mg} / \mathrm{mg} \mathrm{w} 2017$ ).

Średnia zawartość lignin, dla badanej grupy 20 linii grochu, była niższa od notowanej w 2017 roku o 1,9\%. Linia Carneval była linią mniej wylegającą niż MP1401 w III terminie. Analiza korelacji pomiędzy procentową zawartością lignin $\mathrm{w}$ łodydze, a wyleganiem i wysokością roślin wykazała negatywną istotną korelację $(\mathrm{p}<0,01)$ pomiędzy zawartością lignin w łodydze, a wyleganiem w I terminie oraz z wysokością roślin, a także pozytywną w III terminie. Łączy się to z wcześniejszymi wynikami uzyskanymi w ramach Postępu Biologicznego. Stwierdzono wówczas ujemną korelację wylegania w 1 i 2 terminie z wysokością rośliny.

Prace nad uzupełnieniem mapy genetycznej zmierzały do nałożenia QTL gospodarki azotowej grochu. Wykryto 18 QTL dla cech związanych z gospodarką azotową w warunkach kontrolowanych oraz 23 QTL w populacji [Wt10245×Wt11238]. Ciekawym rejonem wydaje się być rejon w VB grupie sprzężeń w pobliżu markera GAPA w pop. [Carneval $\times \mathrm{MP1401}$ ] i markerów $c p$, te $\mathrm{w}$ populacji [Wt10245×Wt11238] warunkujący NERg efektywność wykorzystania azotu w formowaniu masy nasion, w pop. [Carneval $\times$ MP1401] i NAC ilość pobranego azotu/ wazon oraz NERv efektywność wykorzystania azotu $\mathrm{W}$ formowaniu masy wegetatywnej $\mathrm{w}$ populacji [Wt10245×Wt1 1238].

\section{LITERATURA}

Fischinger S. A., Schulze J. 2010. The importance of nodule $\mathrm{CO}_{2}$ fixation for the efficiency of symbiotic nitrogen fixation in pea at vegetative growth and during pod formation. J. Exp. Bot. 61 (9): 2281 2291.

Gaj R. (red.) 2013. Efektywne wykorzystanie składników mineralnych z nawozów we współczesnym rolnictwie. Centrum Doradztwa Rolniczego w Brwinowie, Oddział w Poznaniu, Poznań. 
